\title{
Using ZLD technique for safe and economic disposal of desalination plant brines in Egypt
}

\author{
Reda M. A. Hassan \\ Environment and climate change Research Institute, National Water Research Center \\ E-mail: Doctor_reda2010@yahoo.com
}

\begin{abstract}
Water shortage is one of the greatest problems of modern societies, because of the increase in world population and the fast economic development. In Egypt water requirements is expected to increase from 63 milliard cubic meters in 1997 to 83 milliard cubic meters in 2025. In addition to the fresh water from the Nile River and groundwater, desalination of brackish and sea water is inevitable. The contribution of desalination to drinking water supply is expected to be more than 0.5 million cubic meters per day in the year 2025. However, the widespread of brine discharges to the sea and inland as wastewater from desalination plants may affect environment. This paper assesses the possibility of using the zero liquid discharge (ZLD) technique as a possible solution for the brine disposal problems. Thinking about a Zero Liquid Discharge processes is one of the most attractive solutions to the brine environmental dilemma. ZLD refers to process that fully remove water from the reject brine stream, so the end product is a solid deposit of precipitate salts. In Zero Liquid Discharge Desalination, not only brines will stop to be an environmental menace, but also the recovery of the desalination process will reach values near the $100 \%$. ZLD has been regarded for many years as an uneconomic solution and, therefore was engaged in limited cases. However, the increasing rate of population growth, shortage of water in many places around the world and the growing understanding about the need for environment protection has brought this issue back to focus. This paper presents feasibility for salt production from brine using ZLD technique. It concentrates on reverse osmosis type of desalination plants in Egypt. The aim of this paper is to demonstrate the amounts of brine salts nowadays and the expected amounts in 2025 in Egypt. It presents also economical feasibility of a new brine treatment system in order to decrease the total volume of brines generated and even achieve the zero liquid discharge in desalination processes. On the top of mitigating the negative environmental impacts, additional distilled water and salts were estimated to assess the possible economic return of ZLD introduction to the desalination process in Egypt. It could be concluded from the study that, the introduction of ZLD technique to reverse osmosis desalination plants in Egypt, would viable and has economic and environmental return. It could be recommended that, more attention should be paid for ZLD case studies in Egypt, using real economic models.
\end{abstract}

Key words: Brine Salts-Desalination Plants in Egypt-Economic Return -ZLD Technique

\section{INTRODUCTION}

The water demands increased significantly due to the rapid increase in population and the different purposes of sustainable developments. So it was necessary to search for non-traditional ways to bridge the gap between the currently available water and the deficit of water. The Zero Liquid Discharge desalination project website (2013-2017); which is known as ZELDA project stated in its website that; desalination is used in 150 countries around the world, and currently there are near 16000 desalination plants worldwide producing fresh water from both seawater 
and brackish water. ZELDA also stated that; the global capacity of all desalination plants worldwide is up to 66 million $\mathrm{m}^{3} \cdot \mathrm{day}^{-1}$, which involves a brine production of at least 30 million $\mathrm{m}^{3} \cdot \mathrm{day}^{-1}$. In the case of the Mediterranean region growth predictions expect an increase of $180 \%$ in the desalination capacity the total global capacity is expected to reach 94 million $\mathrm{m}^{3} \cdot \mathrm{day}^{-1}$ by 2015. Thus, the environmental impact generated by this technology will also increase.

Desalination is widely used in some areas in Egypt as a main source for fresh water supply for domestic sector due to the scarcity of renewable natural fresh water resources. Some other areas have already started building desalination plants. The largest number of desalination plants can be found in the Sinai and Red sea area. The ministry of investment 2008 in Egypt reported in its study about desalination Plants and drinking water that; the number of desalination plants in Egypt has been reached about 110 in year 2000; from them 99 plants are reverse osmosis types. In year 2013 the number of desalination plants became about 194 desalination plants; from them 175 plants are reverse osmosis types. The total capacities of desalination plants to produce freshwater were about $185000 \mathrm{~m}^{3} /$ day in year 2000 . The expected amount of produced fresh water is going to be more than $350000 \mathrm{~m}^{3} /$ day in year 2015; if the rate of growth stills the same as $4.4 \%$ as the period from 2000 to 2007. (Dawoud, 2006) stated that; wastewater from desalination plants are known by brine, concentrate or reject water. By definition, brine is any water stream in a desalination process that has higher salinity than the feed. Reject brine is the highly concentrated water in the last stage of the desalination process that is usually discharged as wastewater.

Ahmed et al. (2000) studied the disposal of brine in evaporation bonds and concluded that due to the presence of different chemicals at variable concentrations, reject brine discharged to the sea has the ability to change the salinity, alkalinity and the temperature averages of the seawater and can cause change to marine environment. The characteristics of reject brine depend on the type of feed water and type of desalination process. They also depend on the percent recovery as well as the chemical additives used. They also studied disposal and management of desalination brine and they found that the potential for desalination brine mining may lie in the future with advancements in technology. The cost of desalination and mineral extraction would have to decrease and the efficiency of extraction would need to increase. However, brine mining for raw materials may be carried out for reasons of resource security, though this will have to be balanced against higher production costs. Although technological advances have resulted in the development of new and highly efficient desalination processes; little improvements have been reported in the management and handling of the major by-product waste of most desalination plants, which namely reject brine. The disposal or management of desalination brine (concentrate) represents major environmental challenges to most plants, and it is becoming more costly. In spite of the scale of this economic and environmental problem, the options for brine management for inland plants have been rather limited.

Caterina et al. (2011) studied the brine mining; the study showed that; the challenge is to consider the brine, instead of a harmful by-product, as a valuable source for several compounds to be involved in diverse industrial processes. For example, the brines could provide significant amounts of magnesium, resulting in a very promising source of this element as an alternative to traditional mining. As traditional approaches in mining are costly in time or inapplicable in abandoned and remote regions, research needs to be focused on nontraditional sources such as brines coming from desalination plants. These brines certainly have several advantages, and in time can replace, at least in part, the conventional sources with an alternative, economically 


\section{Using ZLD technique for safe and economic disposal of desalination plant brines in Egypt}

attractive process. Dual benefits can be achieved in recovering and recycling $\mathrm{Mg}$ from reject brines reduction of large volumes of brines to be discharged, as well as decrease of environmental concerns due to industrial extraction from silicate minerals.

Bardi (2010) studied the energy analysis of minerals extraction from seawater and concluded that the concept of recovering minerals from seawater has been proposed as a way of counteracting the gradual depletion of conventional mineral ores. Seawater contains large amounts of dissolved ions and the four most concentrated metal ones $(\mathrm{Na}, \mathrm{Mg}, \mathrm{Ca}, \mathrm{K})$ are being commercially extracted today. It was concluded from the study that the oceans contain vast quantities of dissolved metal ions which in principal could be extracted. Seawater brine mining has long been carried out for obtaining common salt, and currently four metal ions are extracted from brine: sodium, magnesium, calcium and potassium. Bardi (2010) also stated that; recently the rise in commodity prices has spurred interest in brine mining as a possible source of other raw materials and as a means of solving resource security issues. Desalination residues are currently regarded as a waste that must be disposed of. They are highly saline and so can have a negative environmental impact if returned to the sea. The residues could be mined for sodium, magnesium, calcium and potassium but interest has also been expressed in using these brines to obtain the next four elements with the largest oceanic concentrations: lithium, barium, molybdenum and nickel. Energy requirements are determined by concentration. The extraction from low concentration resources, no matter in seawater or in the earth's crust, is expensive in terms of the energy needed. Most elements extraction from seawater is so energy expensive that it must be considered beyond our possibilities in the short and medium term. The exceptions are the four high concentration elements already being commercially extracted $(\mathrm{Na}, \mathrm{Mg}$, $\mathrm{Ca}, \mathrm{K})$. It has to evaluate the prospects for obtaining minerals from desalination brines and to assess the quantities of minerals that could be obtained.

Saudi press agency (2013) announced that, Saudi Arabia is planning to build the largest desalination plant in the world. This will have a capacity of $600,000 \mathrm{~m}^{3}$ of drinking water per day. Assuming that three tones of seawater are required for every tone of drinking water produced, this amounts to around 657 million $\mathrm{m}^{3}$ per year of water passing through the desalination plant. Mickley (2004) compared the operating costs of three ZLD system designs, including a thermal evaporator plus evaporation ponds (1), a high recovery RO plus thermal evaporation plus evaporation ponds (2) and a high recovery RO plus evaporation ponds (3). Option 3 turned out to be most cost-efficient. Cost savings of about $40 \%$ compared to the alternatives were calculated due to the absence of energy-intensive evaporators. Options 2 and 3 require the use of chemicals in the RO process, so that costly sludge disposal must be included in the calculations. In order to become more cost-efficient, ZLD must make use of salt recovery and commercial exploitation. Technologies already exist to selectively remove salts. Other trends might help to make ZLD more competitive in the future.

\section{Objectives}

\section{Cost benefit analysis of brine disposal from desalination plants}

The objective of this study is to discuss the introduction of zero liquid discharge (ZLD) technique to existing reverse osmosis desalination plants in Egypt which contribute to 90\% of desalinated water in the country. An economic and financial evaluation for the ZLD produced salts was carried out to ensure the feasibility of the proposed technique.

Then the variables which are affecting the brine investment are the cost of extracted salts (ES), the cost of new desalinated water from brine (AW), the cost of brine disposal by traditional 
Reda M. A. Hassan

methods (CBD), the cost of zero liquid discharge units (CZLD), and the cost of environmental preservation (CEC). The equation which represents the cost benefit analysis factor of brine (BCB) can be written as follows

$(\mathrm{BCB})=(\mathrm{ES})+(\mathrm{AW})+(\mathrm{CBD})-(\mathrm{CZLD})+(\mathrm{CEC})$

Where:-

$\mathrm{BCB}$ is the brine cost benefit analysis factor;

ES is the cost of extracted salts;

AW is the cost of new desalinated water from brine;

CBD is the cost of brine disposal by traditional methods;

CZLD is the cost of zero liquid discharge units;

$\mathrm{CEC}$ is the cost of environmental preservation.

The term (BCB) is directly proportional to (ES), (AW), and (CBD). But inversely proportional to the term (CZLD), the term (CEC) can be neglected in present financial analysis and calculations, but it is very important for environment; and governments should take it into their considerations.

\section{METHODOLOGY}

Achieving the goals of this paper needs a lot of calculations and economic and financial evaluation for the above mentioned factors to ensure the feasibility of the proposed technique. The calculations included:

- Calculations of new desalinated water quantity and cost from brine (AW)

- Cost of brine disposal by traditional methods (CBD)

- Cost of zero liquid discharge units (CZLD)

- Expected increase in numbers of desalination plants

- Expected brine water of desalination plants using sea water as a source of feeding water and product water rate.

- Expected salts from brine water of desalination plants (RO) system using sea water as a source of feeding water

- Expected values of brine salts from desalination plants (RO) system using sea water as a source of feeding water

- Cost of extracted salts (ES)

\section{RESULTS AND ANALYSES}

More than forty four (44) excel spread sheets had been carried out to achieve the goal of this research, where the study aims to, solving the problem of brine disposal from desalination plants, in particular the reverse osmosis type which comprises $90 \%$ of desalination plants in Egypt, the solution starts from knowing the currently and expected amounts of brine water and ended by suggesting adding evaporators, pumps, packaging units, auxiliary equipment, and crystallizers to RO plants as hybrid unit, the added equipment will constitute zero liquid discharge (ZLD) technique, consequently the prices of all parts were gathered from specified internet sites, according to the international prices in 2014 , where the transportation and marketing were not included in the prices. The analysis depended on the previous studies, which are concerned in economic return of brine calculations (Bardi, 2010; CAIIR, 2012; I.E.S. 2007; 


\section{Using ZLD technique for safe and economic disposal of desalination plant brines in Egypt}

Mickley, 2004; Mohamed et al., 2005); Robin ,(2003); Saudi Press Agency, 2012; SAWPA's Brine Line, 2014).

\section{Calculations of new desalinated water quantity and cost from brine (AW)}

The cost of desalinated water from the RO plants is dependence on many factors like water salinity, source of water brackish or sea water, technology of desalination, the energy used, the capacity of plant if it is more or less than one million gallon per day or ten million gallon per day (1MGD or $10 \mathrm{MGD}$ ), the method of disposing brine and other factors, but references mentioned that the cost of desalinated cubic meter ranges from 0.75 to $1.25 \$$ (El Banna H., 2001), the term (AW) will be 0.75 to $1.25 \$$ per $\mathrm{m}^{3}$.

\section{Cost of brine disposal by traditional methods (CBD)}

The cost of the brine disposal plays an important role in the selection of the method as it could range from 5 to $33 \%$ of the total cost of desalination (Mohamed et al., 2005). The cost of brine disposal from desalination plants is about \$250,000 for 1MGD and the cost of 1galoon/day is equal to $\$ 0.25 \times 10^{-3}$ (after,SAWPA's Brine Line), then the cost of $1 \mathrm{~m}^{3}$ of brine will be $\$ 0.066$. Robin A. Foldager (2003) studied the economic return of different traditional methods of brine disposal from desalination plants; the methods which had been studied were the inland brine disposals include deep-well injection and the storage in evaporation ponds. Another concentrate disposal method centers on the use of salinity gradient solar ponds (SGSPs). Solar pond technology provides an avenue for utilizing reject concentrate to power the desalination unit. These costs are calculated by updating an economic model developed in 1992. The results of calculations showed that costs associated with each disposal option have gone down over time and that evaporation ponds usually present the lowest cost alternative.

The costs of different methods of brine disposal for 1000 gallon /day are:

$\begin{array}{llcccc}\text { No. } & \text { Type of brine disposal } & 1 \mathrm{MGD} & \mathrm{M}^{3} / \mathrm{d} & 10 \mathrm{MGD} & \mathrm{M}^{3} / \mathrm{d} \\ 1- & \text { evaporation ponds } & \$ 0.38 / 1000 \mathrm{~g} / \mathrm{d} & \$ 0.10 & \$ 0.38 / 1000 \mathrm{~g} / \mathrm{d} & \$ 0.10 \\ 2- & \text { deep-well injection } & \$ 2.79 / 1000 \mathrm{~g} / \mathrm{d} & \$ 0.74 & \$ 2.09 / 1000 \mathrm{~g} / \mathrm{d} & \$ 0.55 \\ \text { 3- } & \begin{array}{l}\text { salinity gradient solar } \\ \text { ponds }\end{array} & \$ 2.78 / 1000 \mathrm{~g} / \mathrm{d} & \$ 0.73 & \$ 1.95 / 1000 \mathrm{~g} / \mathrm{d} & \$ 0.52\end{array}$

Then the cost of brine disposal (CBD) can be taken as $\$ 0.066$ to $\$ 0.74$ for $\mathrm{m}^{3} /$ day

\section{Cost of zero liquid discharge units (CZLD)}

The ZLD System removes dissolved solids from the wastewater and returns distilled water to the process. Reverse osmosis (membrane filtration) may be used to concentrate a portion of the waste stream and return the clean permeate to the process. In this case, a much smaller volume (the reject) will require evaporation, thus enhancing performance and reducing power consumption. In many cases, falling film evaporation is used to further concentrate the brine prior to crystallization. These crystals are removed and dewatered. The water vapor from evaporation is condensed and returned to the process. Solids from pretreatment are generally mechanically dewatered in a plate-and-frame filter press. The filtrate is simply recycled back to the beginning of the pretreatment system. The crystals from the crystallization process can also be mechanically dewatered, but corrosion resistant materials are usually necessary due to the high salt concentrations present. The crystals can be dewatered in a filter press or centrifuge allowing much higher solids concentrations as a result. The filtrate (or concentrate) is then 


\section{Reda M. A. Hassan}

returned to the crystallizer as shown in Figure (2) (I.E.S. 2007). The process can be repeated and the produced salts can be packaged to be ready for marketing, the new produced distilled water can be directed to the product water of the plant as a new added value for the ZLD process. From the aforesaid steps of ZLD system, it could be concluded that the main important parts in the system are the evaporator, and the crystallizer. The pumps and dryers are auxiliary parts, but for brine investment a packaging unit should be added to the system to bind the extracted salts in sacks or plastic covers for commercial use. Then the cost of (CZLD) will include the capital cost (constructions- main and auxiliary equipment-testing and commissioning), the operation and maintenance cost which include (salaries-chemicals-fuel-spare parts-other consuming materials) and training, management and research activities, the percentages of different costs can be quoted from the cost of desalination plants as shown in Table (1) (El Banna , 2001).

Then the cost of (CZLD) according to the capacity of the desalinated plants, for plants equal or less than $\leq 150 \mathrm{~m}^{3} /$ day, will be as follow, according to the international prices of equipment in 2014 (Http://offer.alibaba.com).

Evaporator cost $=4$ (evaporators) $\times \$ 50000$ (evaporator price) $=\$ 200000$, it needs four evaporators where the evaporation rate equal 48m3/day,

Crystallizer cost $=4 \mathrm{x} \$ 40000=\$ 160000$

Auxiliary unit cost $=4 \mathrm{x} \$ 20000=\$ 80000$

Packaging unit cost $=\$ 80000$, Total capital cost $=\$ 520000$

Operation and maintenance cost $=43 \% \times \$ 520000=\$ 223600$

Total cost $==\$ 520000+\$ 223600=\$ 743600$

Getting the cost of ZLD technique unit needs to calculate the amortization factor of equipment loan with yearly interest rate $(6 \%)$ and equipment life (30 years) using this equation. The amortization capital cost $(\mathrm{ACC})=(\mathrm{TCC}) / \mathrm{M}=\$ 743600 / \mathrm{M}=\$ 743600 / 13.69=\$ 54,317$.

Where $M$ (amortization factor of equipment loan) $=\left((1+\mathrm{i})^{\mathrm{n}}-1\right) / \mathrm{i} \times(1+\mathrm{i})^{\mathrm{n}}$

$$
=(1+0.06)^{30}-1 / 0.06 \mathrm{x}=(1+0.06) 30=13.69
$$

Where $\mathrm{I}$ is the yearly interest rate $(6 \%)$ and $\mathrm{n}$ is the equipment life (30 years)

$\mathrm{CZLD}=((\mathrm{ACC})+(\mathrm{OM})) / \mathrm{Pa}=(\$ 54,317+\$ 223600) / \mathrm{pa}=\$ 277917 / 54750 \mathrm{~m}^{3} / \mathrm{year}=5.076 \$ / \mathrm{m}^{3}$

$\mathrm{Pa}$ is the annually product water $=$ daily unit capacity $\mathrm{x} 365$ days

$$
=365 \text { days } x 150 \mathrm{~m}^{3} / \mathrm{d}=54750 \mathrm{~m}^{3} / \text { year }
$$

The cost of brine disposal using ZLD technique for $1 \mathrm{~m}^{3}=5.076 \$ / \mathrm{m}^{3}$

\section{Expected increase in numbers of desalination plants}

Solving the problem of reject water (brine) in Egypt starts from the determination of quantity and quality of brine from desalination plants. Data were collected for years 2000 to 2007 as shown in Table (2), to get the rate of change in numbers of desalination plants in Egypt during this period, so the following equation can be used to get the rate of change in the number of desalination plants $R_{d}$.

$\mathrm{R}_{\mathrm{d}}=\sum\left(\mathrm{X}_{\mathrm{n}}-\mathrm{X}_{\mathrm{n}-1}\right) / \mathrm{N} \times 100$

Where:-

$R_{d}=$ the rate of change in the number of desalination plants

$\mathrm{X}_{\mathrm{n}}=$ the number of desalination plants at assigned year (n)

$\mathrm{X}_{\mathrm{n}-1}=$ the number of desalination plants at pre-assigned year

$\mathrm{n}=$ the number of assigned year (according to available collected data) 


\section{Using ZLD technique for safe and economic disposal of desalination plant brines in Egypt}

$\mathrm{N}=$ the number of total assigned years

$\mathrm{R}_{\mathrm{d}}=\sum(\mathrm{Xn}-\mathrm{Xn}-1) / \mathrm{N} \times 100=(115-110)+(120-115)+(125-120)+$

$$
(131-125)+(137-131)+(143-137)+(149-143) / 8=0.048
$$

The expected increase in numbers of desalination plants $I_{x+1}$ for the subsequently year can be obtained from the following equation:

$\mathrm{I}_{(\mathrm{x}+1)}=\left(1+\mathrm{R}_{\mathrm{d}}\right) \times \mathrm{X}_{\mathrm{n}}$

Where:-

$\mathrm{R}_{\mathrm{d}}=$ the rate of change in the number of desalination plants

$\mathrm{X}_{\mathrm{n}}=$ the number of desalination plants at assigned year (n)

$\mathrm{I}_{(\mathrm{x}+1)}=$ the expected increase in numbers of desalination plants for the subsequently year

$\mathrm{n} \quad=$ the number of assigned year

$\mathrm{I}_{(\mathrm{x}+1)}=\left(1+\mathrm{R}_{\mathrm{d}}\right) \times \mathrm{X}_{\mathrm{n}}=1.048 \times \mathrm{Xn}$

The expected increase in numbers of desalination plants for years 2008, 2009, 2014 and 2025 will be as follows:

$\mathrm{I}_{2008}=1.048 \times \mathrm{X}_{2007}=1.048 \times 149=156$

$\mathrm{I}_{2009}=1.048 \times \mathrm{X}_{2008}=1.048 \times 156=163$

$\mathrm{I}_{2014}=1.048 \times \mathrm{X}_{2013}=1.048 \times 194=203$

$\mathrm{I}_{2025}=1.048 \times \mathrm{X}_{2024}=1.048 \times 314=329$

The number of reverse osmosis plants (RO) is about $90 \%$ of the total amount of desalination plants, in Egypt. The number of all types of other plants is about $10 \%$, then for this reason it will be focused on the reverse osmosis plants, in this research. Then the expected increase in numbers of (RO) desalination plants for year 2008, 2009 and 2014 will be as follows:-

$\mathrm{I}_{2008}=1.048 \times \mathrm{X}_{2007} \times 0.9=1.048 \times 149 \times 0.9=140$

$\mathrm{I}_{2009}=1.048 \times \mathrm{X}_{2008} \times 0.9=1.048 \times 156 \times 0.9=147$

$\mathrm{I}_{2014}=1.048 \times \mathrm{X}_{2013} \times 0.9=1.048 \times 194 \times 0.9=183$

$\mathrm{I}_{2025}=1.048 \times \mathrm{X}_{2024} \times 0.9=1.048 \times 314 \times 0.9=296$

The expected increase in total number of desalination plants and the expected increase in total number of (RO) desalination plants from year 2000 to 2025 were calculated and tabulated as shown in Tables (3).

\section{Expected brine water from desalination plants Sea water as a source of feeding water * Product water rate (Sea Water)}

In this research the available data is the product water rate (PWR), then getting the reject water rate (RWR) needs to substituting in the following equation:-

Recovery Rate $\%=$ Product water Rate $\div$ Feed Water Rate $=20 \%-40 \%$

Then, Feed Water Rate $=$ Product water Rate $\div(20 \%-40 \%)$

Then, Maximum Feed Water Rate $=$ Product water Rate $\div(20 \%)$

And, Minimum Feed Water Rate $=$ Product water Rate $\div(40 \%)$ 


\section{Reject water rate (Sea Water)}

The brine water rate (BWR) can be obtained from the percentage of rejected water rate, where the percentage of brine water rate of sea water equal $60 \%$ to $80 \%$ of feed water rate(FWR), as shown in Table (3), then the minimum and maximum Amount of brine water can be obtained from these equations:-

In Egypt, the total amount of product water rate was $185724 \mathrm{~m}^{3} /$ day for year 2000 , then the maximum Amount of brine water, when sea water is the feeding source is Brine Water Rate $($ maximum $)=4(\mathrm{PWR})=4 \times 185724 \mathrm{~m}^{3} /$ day $=742896 \mathrm{~m}^{3} /$ day Brine Water Rate $($ minimum $)=1.5(\mathrm{PWR})=1.5 \times 185724 \mathrm{~m}^{3} /$ day $=278586 \mathrm{~m}^{3} /$ day

The number of reverse osmosis plants (RO) is about $90 \%$ of the total amount of desalination plants, in Egypt.

Then, Brine Water Rate (maximum) for $(\mathrm{RO})$ plants $=4(\mathrm{PWR}) \times 0.90$

$$
=4 \times 0.90 \times 185724 \mathrm{~m}^{3} / \text { day }=668606 \mathrm{~m}^{3} / \text { day }
$$

Brine Water Rate (minimum) for $(\mathrm{RO})$ plants $=1.5(\mathrm{PWR}) \times 0.90=250727 \mathrm{~m}^{3} /$ day

The number of all types of other plants is about $10 \%$, then for this reason it will be focused on The reverse osmosis plants, in this research. Then the minimum and maximum brine water rate for (RO) desalination plants, also the expected increase in brine water rate for years 2000 to 2025, were calculated and tabulated as shown in Table (4).

\section{Expected salts from brine water of desalination plants (RO) system Sea water as a source of feeding water}

The total amounts of dissolved salts can be achieved from sea water as a source of feeding water for year 2000, the minimum and maximum Dissolved salts for RO type plants from these equations:

Minimum dissolved salts for $(\mathrm{RO})$ plants (ton /day) $=$ total amount of desalinated water $\times 0.90 \times$ $1.5 \times 0.003=185724 \mathrm{~m}^{3} /$ day $\times 0.90 \times 1.5 \times 0.003 \mathrm{ton} / \mathrm{m}^{3}=8525$ ton $/$ day

Maximum salts for $(\mathrm{RO})$ plants $($ ton $/$ day $)=$ total amount of desalinated water $\times 0.90 \times 4 \times 0.003$

$$
=185724 \mathrm{~m}^{3} / \text { day } \times 0.90 \times 4 \times 0.003 \mathrm{ton} / \mathrm{m}^{3}=22733 \text { ton } / \text { day }
$$

The minimum and maximum of salts for (RO) desalination plants, also the expected salts for years 2000 to 2025, were calculated and tabulated as shown in Table (5).

\section{Expected values of brine salts from desalination plants (RO) system}

The prices of different components of brine water can be calculated according to the international prices of each component, as shown in Table (6).

\section{Sea water as a source of feeding water}

The cost of the brine disposal plays an important role in the selection of the method as it could range from 5 to $33 \%$ of the total cost of desalination (Mohamed et al., 2005). The total daily and yearly amounts of salts can be achieved, from sea water as a source of feeding water, for years 2014 to 2025, also the minimum and maximum expected prices for these amounts of salts will be achieved for reverse osmosis type plants from these equations:- 


\section{Using ZLD technique for safe and economic disposal of desalination plant brines in Egypt}

Total yearly income of salt $(\$ /$ year $)=$ total daily amount of salt $\left(\mathrm{t} / \mathrm{m}^{3}\right) \times$ concentration of assigned salt $\left(\mathrm{t} / \mathrm{m}^{3}\right) \times$ international price of assigned salt $(\$) \times 365$ days

Minimum total yearly income of salt $(\$ /$ year $)=$ minimum total daily amount of salt $\left(\mathrm{t} / \mathrm{m}^{3}\right) \times$ concentration of assigned salt $\left(\mathrm{t} / \mathrm{m}^{3}\right) \times$ international price of assigned salt $(\$) \times 365$ days

Maximum total yearly income of salt $(\$ /$ year $)=$ minimum total daily amount of $\mathrm{salt}\left(\mathrm{t} / \mathrm{m}^{3}\right) \times$ concentration of assigned salt $\left(\mathrm{t} / \mathrm{m}^{3}\right) \times$ international price of assigned salt $(\$) \times 365$ days

The amount of each component and its percentage in brine solution and the international prices can be achieved from as said before.

The minimum total yearly price for sodium chloride salt $\mathrm{NaCl}$, for years 2014 and 2025 will be as follows:

Minimum total yearly income of salt $\mathrm{NaCl}(\$ /$ year $)=$ minimum total daily amount of salt $15673.5(\mathrm{t} / \mathrm{d}) \times$ Concentration of assigned salt $0.000023476\left(\mathrm{t} / \mathrm{m}^{3}\right) \times$ international price of assigned salt $150(\$ / \mathrm{t}) \times 365$ days $=20145.3 \times 1000=20145300(\$ /$ year $)$

Maximum total yearly income of salt $\mathrm{NaCl}(\$ /$ year $)=$ maximum total daily amount of salt $41796.0(\mathrm{t} / \mathrm{d}) \times$ Concentration of assigned salt $0.000023476\left(\mathrm{t} / \mathrm{m}^{3}\right) \times$ international price of assigned salt $150(\$ / \mathrm{t}) \times 365$ days $=53720.9 \times 1000=53720900(\$ /$ year $)$

The maximum and minimum total yearly prices for all salts were tabulated in table (7) for the period from 2014 to 2025 , will be as follows:

Minimum total income of salts for the period from 2014 to $2025(\$)=\$ 599240100$

Maximum total income of salts for the period from 2014 to $2025(\$)=\$ 1584973000$

\section{Cost of extracted salts (ES)}

The salts which constitute more than $97 \%$ of brine solution are $\mathrm{NaCl}, \mathrm{MgCl}_{2}, \mathrm{CaCl}_{2}$, and $\mathrm{Na}_{2} \mathrm{SO}_{4}$. The international prices of these salts are not including transportation and marketing; the prices are according to the international prices in 2014 (Http://offer.alibaba.com).

The average prices $=(150+400+120+150) / 4=205 \$ /$ ton

For one cubic meter of brine the amount of salts will be $34.4 \mathrm{~kg} / \mathrm{m}^{3}$.

For ZLD the evaporated sea water should be $100 \%$ and contains $5 \%$ of dissolved salts, and then the salts would be $0.95 \% \times 34.4 \mathrm{~kg} / \mathrm{m}^{3}$.

The salts in $1 \mathrm{~m}^{3}=.97 \times 0.95 \times 0.0344=0.0317 \mathrm{ton} / \mathrm{m}^{3}$, for $\mathrm{RO}$ plants the recovery ratio is $35 \%$ to $45 \%$, then the concentration of salts in brine will be $1.535 \times 0.0317 \mathrm{ton} / \mathrm{m} 3=0.048 \mathrm{ton} / \mathrm{m}^{3}$. The value of extracted salts from $1 \mathrm{~m}^{3}$ of brine $=0.048 \mathrm{ton} / \mathrm{m}^{3} \times 205 \$ /$ ton $=9.97 \$ / \mathrm{m}^{3}$.

Applying equation (1) of economic return for brine disposal, then $(B C B)=9.97 \$ / \mathrm{m} 3+$ $0.75 \$ / \mathrm{m}^{3}+\$ 0.066-5.076 \$ / \mathrm{m}^{3}+0.0=5.71 \$ / \mathrm{m}^{3}$

Brine cost benefit analysis factor (BCB) will be $5.71 \$ / \mathrm{m}^{3}$

The survey of the data and calculation showed that the present desalination plants in 2014 were 203 different plants, the reverse osmosis plants were 182 plants, and these numbers are 
matching with the same numbers in (El Banna H., 2001). plainly from the analysis, it is obvious that the percentage of the reverse osmosis plants is about $90 \%$ of these plants, this percent is very important for the decision maker to decide which type is the most valuable for investment.

The calculation of gathered data showed that the expected number of different types of desalination plants in 2025 will be 327 plants, using rate of change $4.8 \%$ per year increasing in desalination plants, from these plants 295 plants of (RO) type.

According to the calculations of the currently total amount of brine water from desalination plants in Egypt, and the expected brine water in 2025, also the expected total amount of dissolved salts in 2025 which were presented in the methodology, and from the tabulated data in Tables $(6 \& 8)$.

The calculations revealed that, for present year 2014 the total minimum and maximum amounts of brine water from RO type of desalination plants were 460,985 $\mathrm{m}^{3} /$ day and 1,229,294 $\mathrm{m}^{3} /$ day, when using sea water as a source of feeding water.

Also the expected total minimum and maximum amounts of brine water from RO type of desalination plants, for year 2025 will be $743,870 \mathrm{~m}^{3} /$ day and $1,983,654 \mathrm{~m}^{3} /$ day.

After obtaining the total amounts of brine, several excel spread sheets were carried out to calculate the total amount of each salt in the brine, and its income according to the international prices in year 2014, for the enhancement of these salts, which can be collected to use it in different agricultural and industrial purposes by analyzing and assessing the amounts and prices of these salts.

The calculations showed that, for all RO plants in Egypt the salt $(\mathrm{NaCl})$ has the biggest total yearly amounts and income during 12 years from (2014 to 2025), where the minimum income will be $310,560,000 \$ /(12$ years) and maximum income will be $828,160,700 \$ /(12$ years).

To study the economic aspects of salts, as an opportunity for investment and as a new source of foreign currency, the yearly income for each salt in the brine for reverse osmosis (RO) type of desalination plants, had been calculated for the period from 2014 to 2025, the calculated data was shown in table (8).

It was obvious that from table (8), the total maximum income for all RO plants in Egypt, for all salts in brine will be 1,584,973,000\$/12years. Also the return income of salts $\mathrm{NaCl}$, $\mathrm{MgCl}_{2}, \mathrm{Na}_{2} \mathrm{So}_{4}, \mathrm{CaCl}_{2}$ and $\mathrm{KCl}$ are more valuable than $\mathrm{NaHCO}_{3}, \mathrm{KBr}, \mathrm{H}_{2} \mathrm{BO}_{3}, \mathrm{SrCl}_{2}$, and $\mathrm{NaF}$ as shown in Figure (2). after determining currently and expected amounts of brine water and their economic return, without taking into considerations the different costs, of the variables which are affecting the brine investment, for this reason calculations for the cost of one cubic meter of brine had been carried out to compare among these variables, after making the calculation using equation 1 , the calculation showed that the economic return from brine will be more than $5 \$ / \mathrm{m}^{3}$ of brine.

\section{Conclusion and Recommendations}

- It could be concluded from the study that, the usage of ZLD technique for reverse osmosis (RO) type of desalination plants in Egypt, will add more than $5 \$ / \mathrm{m}^{3}$ of brine, then it will be a material of significant usage, and has some opportunities for economic return, finally it will protect environment.

- The brine economic return can be expressed by simple relation, which includes the quantity of extracted salts (ES), the quantity of new desalinated water (added water) from brine (AW), the cost of brine disposal by traditional methods (CBD), the cost of zero liquid discharge units (CZLD), and the cost of environmental conservation (CEC). 


\section{Using ZLD technique for safe and economic disposal of desalination plant brines in Egypt}

- It is concluded also that the percentage of the RO plants in Egypt are about $90 \%$ of all different plants, this information is very important for the decision maker, to decide which type is the most valuable for investment.

- The yearly rate of change in the number of reverse osmosis desalination plants in Egypt is about $(4.8 \%)$. In the future the expected number of different types of desalination plants in 2025 will be 327 plants from which 295 plants of (RO) type.

- The salt $(\mathrm{NaCl})$ has the biggest total daily and yearly amounts and income.

- The return income of salts $\mathrm{NaCl}, \mathrm{MgCl}_{2}, \mathrm{Na}_{2} \mathrm{So}_{4}, \mathrm{CaCl}_{2}$ and $\mathrm{KCl}$ are more valuable than $\mathrm{NaHCO}_{3}, \mathrm{KBr}, \mathrm{H}_{2} \mathrm{BO}_{3}, \mathrm{SrCl}_{2}$, and $\mathrm{NaF}$.

- It is recommended for the future work that, the research of brine mining and safe disposal of brine, with a minimum impact on the environment should be studied.

Table (1). Different \% costs from total production cost of desalination plants (El Banna,, 2001)

\begin{tabular}{|l|l|c|}
\hline No. & Item & $\begin{array}{c}\% \text { of product } \\
\text { water cost }\end{array}$ \\
\hline $1-$ & $\begin{array}{l}\text { Capital cost (constructions- main and auxiliary equipment-testing and } \\
\text { commissioning) }\end{array}$ & $56.3 \%$ \\
\hline $2-$ & The operation cost (salaries-chemicals-fuel) & $24.4 \%$ \\
\hline $3-$ & The maintenance cost (fuel-spare parts-other consuming materials) & $9.2 \%$ \\
\hline $4-$ & Training, management and research activities & $10.2 \%$ \\
\hline $5-$ & Total of operation and maintenance cost & $43.7 \%$ \\
\hline $6-$ & Total cost of production & $100 \%$ \\
\hline
\end{tabular}

Table (2). Total number of all types of desalination plants and RO plants from 2000 to 2007

\begin{tabular}{|l|l|c|c|}
\hline No. & Year & Total number of Des Plants & Total number of (R O) D. Plants \\
\hline $1-$ & 2000 & 110 & 99 \\
\hline $2-$ & 2001 & 115 & 104 \\
\hline $3-$ & 2002 & 120 & 108 \\
\hline $4-$ & 2003 & 125 & 113 \\
\hline $5-$ & 2004 & 131 & 118 \\
\hline $6-$ & 2005 & 137 & 123 \\
\hline $7-$ & 2006 & 143 & 129 \\
\hline $8-$ & 2007 & 149 & 134 \\
\hline
\end{tabular}

Table (3). Expected numbers of all types of desalination plants and RO plants until year 2025

\begin{tabular}{|c|c|c|c|c|c|}
\hline Year & $\begin{array}{c}\text { Total number of } \\
\text { Des. Plants }\end{array}$ & $\begin{array}{c}\text { Total number of RO } \\
\text { Des. Plants }\end{array}$ & Year & $\begin{array}{c}\text { Total number of } \\
\text { Des. Plants }\end{array}$ & $\begin{array}{c}\text { Total number of RO } \\
\text { Des. Plants }\end{array}$ \\
\hline 2008 & 156 & 140 & 2017 & 231 & 208 \\
\hline 2009 & 163 & 147 & 2018 & 241 & 217 \\
\hline 2010 & 170 & 153 & 2019 & 252 & 227 \\
\hline 2011 & 178 & 160 & 2020 & 263 & 248 \\
\hline 2012 & 186 & 167 & 2021 & 275 & 259 \\
\hline 2013 & 194 & 175 & 2022 & 287 & 270 \\
\hline 2014 & 203 & 182 & 2023 & 300 & 282 \\
\hline 2015 & 212 & 191 & 2024 & 314 & 295 \\
\hline 2016 & 221 & 199 & 2025 & 327 & \\
\hline
\end{tabular}


Reda M. A. Hassan

Table (4). The percentage of each salt which formed of brine water by $\mathrm{gm} / \mathrm{m}^{3}$ (I.E.S., 2007)

\begin{tabular}{|c|c|c|c|c|c|c|c|}
\hline \multirow{2}{*}{ Salt } & \multicolumn{2}{|c|}{ Salt percentage } & \multirow{2}{*}{$\mathrm{gm} / \mathrm{m}^{3}$} & \multirow[b]{2}{*}{ Salt } & \multicolumn{2}{|c|}{ Salt percentage } & \multirow[b]{2}{*}{$\mathrm{gm} / \mathrm{m}^{3}$} \\
\hline & $(\%)$ & Mg/liter & & & $(\%)$ & $\mathrm{Mg} / \mathrm{liter}$ & \\
\hline $\mathrm{NaCI}$ & 68.08 & 23.476 & 23.476 & $\mathrm{KBr}$ & 0.278 & 296 & 296 \\
\hline $\mathrm{MgCl}_{2}$ & 14.44 & 4.981 & 4.981 & $\mathrm{H}_{2} \mathrm{BO}_{3}$ & 0.075 & 26 & 26 \\
\hline $\mathrm{Na}_{4} \mathrm{So}_{4}$ & 11.36 & 3.917 & 3.917 & $\mathrm{SrCl}_{2}$ & 0.0696 & 24 & 24 \\
\hline $\mathrm{CaCI}_{2}$ & 3.2 & 1102 & 1.102 & $\mathrm{NaF}$ & 0.0087 & 3 & 3 \\
\hline $\mathrm{NaHCO}_{3}$ & 0.556 & 192 & 192 & Total & & & 34.481 \\
\hline
\end{tabular}

Table (5). The total capacity of desalinated water and brine water.

\begin{tabular}{|c|c|c|c|c|}
\hline \multirow[t]{2}{*}{ Year } & \multicolumn{2}{|c|}{ Total capacity of desalinated water $\mathrm{m}^{3} /$ day } & \multicolumn{2}{|c|}{ Brine water from sea water $(\mathrm{RO}) \mathrm{m}^{3} / \mathrm{day}$} \\
\hline & All types of plants & RO & Min & Max \\
\hline 2000 & 185724 & 167151.6 & 250727 & 668606 \\
\hline 2001 & 193981 & 174583.2 & 261875 & 698333 \\
\hline 2002 & 202606 & 182345.1 & 273518 & 729381 \\
\hline 2003 & 211614 & 190452.2 & 285678 & 761809 \\
\hline 2004 & 221022 & 198919.7 & 298380 & 795679 \\
\hline 2005 & 230849 & 207763.7 & 311645 & 831055 \\
\hline 2006 & 241112 & 217000.8 & 325501 & 868003 \\
\hline 2007 & 251832 & 226648.7 & 339973 & 906595 \\
\hline 2008 & 263028 & 236725.5 & 355088 & 946902 \\
\hline 2009 & 274723 & 247250.3 & 370875 & 989001 \\
\hline 2010 & 286937 & 258243.1 & 387365 & 1032972 \\
\hline 2011 & 299694 & 269724.5 & 404587 & 1078898 \\
\hline 2012 & 313018 & 281716.5 & 422575 & 1126866 \\
\hline 2013 & 326935 & 294241.6 & 441362 & 1176966 \\
\hline 2014 & 341471 & 307323.6 & 460985 & 1229294 \\
\hline 2015 & 356652 & 320987.2 & 481481 & 1283949 \\
\hline 2016 & 372509 & 335258.3 & 502887 & 1341033 \\
\hline 2017 & 389071 & 350163.9 & 525246 & 1400656 \\
\hline 2018 & 406369 & 365732.2 & 548598 & 1462929 \\
\hline 2019 & 424436 & 381992.6 & 572989 & 1527970 \\
\hline 2020 & 443307 & 398976.0 & 598464 & 1595904 \\
\hline 2021 & 463016 & 416714.5 & 625072 & 1666858 \\
\hline 2022 & 483602 & 435241.6 & 652862 & 1740966 \\
\hline 2023 & 505103 & 454592.5 & 681889 & 1818370 \\
\hline 2024 & 527560 & 474803.6 & 712205 & 1899215 \\
\hline 2025 & 551015 & 495913.4 & 743870 & 1983654 \\
\hline
\end{tabular}


Using ZLD technique for safe and economic disposal of desalination plant brines in Egypt

Table (6). The prices in $\$$ per ton of different salts which formed of Brine water

\begin{tabular}{|l|c|c|c|c|c|c|c|c|c|c|}
\hline Salt & $\mathrm{NaCI}$ & $\mathrm{MgCl}_{2}$ & $\mathrm{Na}_{4} \mathrm{So}_{4}$ & $\mathrm{CaCl}_{2}$ & $\mathrm{KCl}$ & $\mathrm{NaHCO}_{3}$ & $\mathrm{KBr}$ & $\mathrm{H}_{2} \mathrm{BO}_{3}$ & $\mathrm{SrCl}_{2}$ & $\mathrm{Na} \mathrm{F}$ \\
\hline prices & 150 & 120 & 400 & 150 & 800 & 210 & 3000 & 900 & 750 & 350 \\
\hline
\end{tabular}

Table (7). The expected salts from brine water of (RO) system

\begin{tabular}{|c|c|c|c|c|c|}
\hline \multicolumn{3}{|c|}{ Sea Water (t/day) } & \multicolumn{3}{c|}{ Sea Water (t/day) } \\
\hline Year & Min.Salts & Max. Salts & year & Min.Salts & Max. Salts \\
\hline 2000 & 8525 & 22733 & 2013 & 15006 & 40017 \\
\hline 2001 & 8904 & 23743 & 2014 & 15674 & 41796 \\
\hline 2002 & 9300 & 24799 & 2015 & 16370 & 43654 \\
\hline 2003 & 9713 & 25901 & 2016 & 17098 & 45595 \\
\hline 2004 & 10145 & 27053 & 2017 & 17858 & 47622 \\
\hline 2005 & 10596 & 28256 & 2018 & 18652 & 49740 \\
\hline 2006 & 11067 & 29512 & 2019 & 19482 & 51951 \\
\hline 2007 & 11559 & 30824 & 2020 & 20348 & 54261 \\
\hline 2008 & 12073 & 32195 & 2021 & 21252 & 56673 \\
\hline 2009 & 12610 & 33626 & 2022 & 22197 & 59193 \\
\hline 2010 & 13170 & 35121 & 2023 & 23184 & 61825 \\
\hline 2011 & 13756 & 36683 & 2024 & 24215 & 64573 \\
\hline 2012 & 14368 & 38313 & 2025 & 25292 & 67444 \\
\hline
\end{tabular}

Table (8). Total annual prices of brine salts for RO system from year 2014 to 2025

\begin{tabular}{|c|c|c|}
\hline \multicolumn{3}{|c|}{ (RO) System Sea water $/ 1000 \$$} \\
\hline Salt & min. & $\max$. \\
\hline$(\mathrm{NaCI})$ & 310560.3 & 828160.7 \\
\hline$\left(\mathrm{MgCl}_{2}\right)$ & 52714.29 & 140571.3 \\
\hline$\left(\mathrm{Na}_{2} \mathrm{SO}_{4}\right)$ & 138179.7 & 368479.1 \\
\hline$\left(\mathrm{CaCI}_{2}\right)$ & 14551.73 & 38804.6 \\
\hline$(\mathrm{KCl})$ & 46706.6 & 124551 \\
\hline $\left.\mathrm{NaHCO}^{3}\right)$ & 3537.39 & 9433.05 \\
\hline$(\mathrm{KBr})$ & 25346.5 & 67590.6 \\
\hline $\mathrm{H}_{2} \mathrm{BO}_{3}$ & 2047.82 & 5460.87 \\
\hline $\mathrm{SrCl}_{2}$ & 5503.2 & 1675.2 \\
\hline $\mathrm{NaF}$ & 92.601 & 246.938 \\
\hline Total & 599240.1 & 1584973 \\
\hline
\end{tabular}


Reda M. A. Hassan

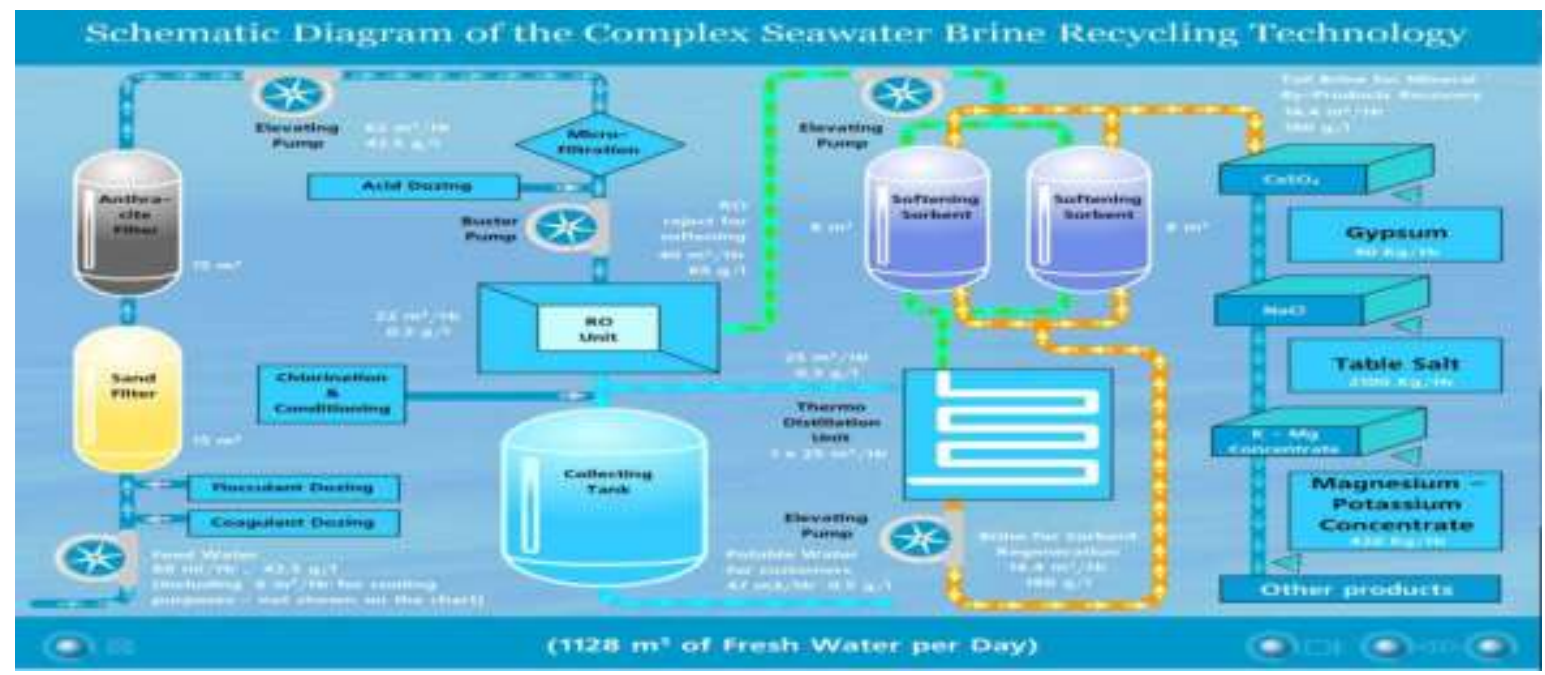

Fig. (1). Schematic of I.E.S zero liquid discharge system for seawater desalination plants (Ref.6)

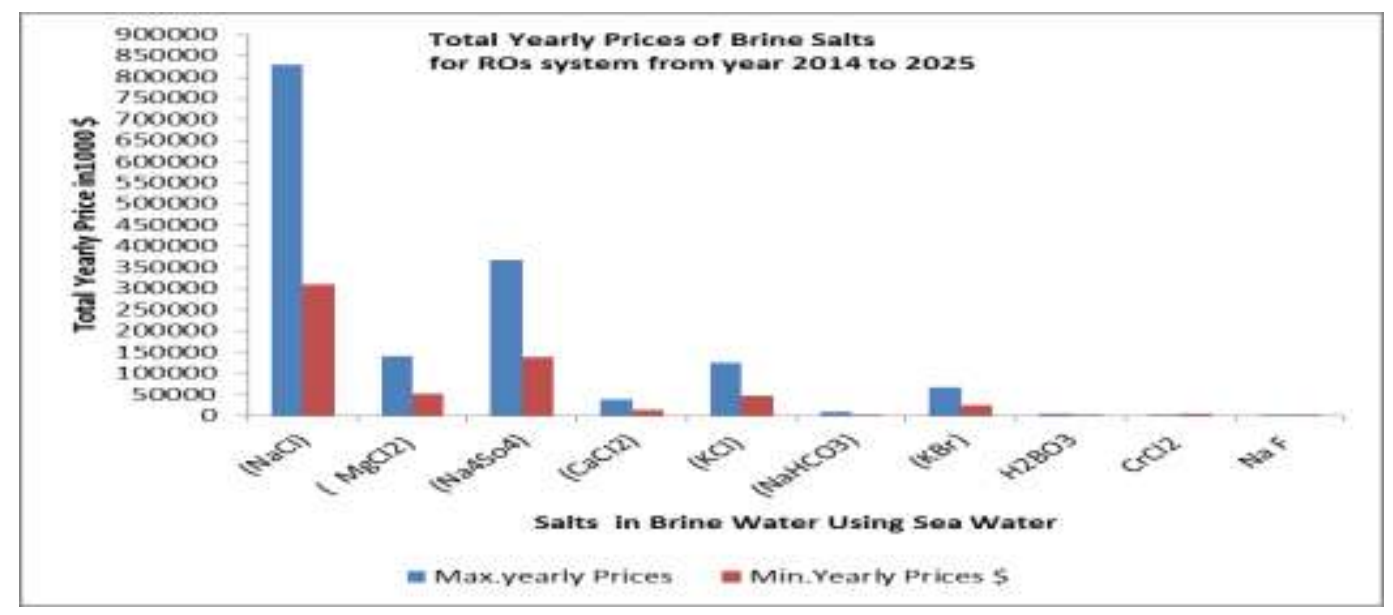

Fig. (2). Total annual values of brine salts for RO system from year 2014 to 2025

\section{REFERENCES}

Ahmed, M.; Shayya, W. H. ; Hoey, D.; Maendran, A.; Morris, R. and Al-Handaly, J. (2000). Use of evaporation ponds for brine disposal in desalination plants. Desalination, 130:155-168

Ahmed, M.; Shayya, W. H. ; Hoey, D. and Al- Handaly, J. (2001). Brine disposal from reverse osmosis desalination plants in Oman and United Arab Emirates. Desalination, 133:135-147.

Bardi, U. (2010). Extracting Minerals from Seawater: An Energy Analysis, Sustainability “2010, p2, p980-p992.

Caterina De Vito , Silvano Mignardi ,Vincenzo Ferrini and Robert F. Martin (2011). Reject Brines from Desalination as Possible Sources for Environmental Technologies. Cited at www.intechopen.com. 


\section{Using ZLD technique for safe and economic disposal of desalination plant brines in Egypt}

CAIIR, Central Administration for Investment and International Relationships (2012). Report of Desalination Plants Series of Sectorial Studies- Sector of Food Industries-Arabic Report, Pages No.36-38-45-47-48.

Dawoud M. A.; Allam A. R.; El Shewey M. A. and Soliman S. M. (2006). Using renewable energy sources for water production in arid regions: GCC countries case study", in Arid Land Hydrogeology

El Banna H., (2001) "Desalination Technology" part no. 1, page no.433, 116, 383, and 68Arabic Text Book, Al Dar Elgamaia- Alexandria.

I.E.S. (2007). I.E.S. [Online] 2007. [Cited: 0503 2008.] http://iestech.com/

Mickley, Michael (2004). Desalination concentrate management and issues in the United States. Texas Water Development Board Desalination Workshop.

Mohamed, A.M.O.; Maraqa, M. and Al Handhaly, J. (2005). Impact of land disposal of reject brine from desalination plants on soil and groundwater. Desalination, 182: 411433.

Robin A. Foldager (2003). Economics of desalination concentrate disposal methods in inland regions: deep-well injection, evaporation ponds, and salinity gradient solar ponds" A thesis submitted to the University Honors Program in partial fulfillment of the requirements for graduation with University Honors Major: Environmental Science New Mexico State University Las Cruces,

Saudi Press Agency (2012). http://www.spa.gov.sa/details.php?id=1077365

SAWPA's Brine Line (Santa Ana Watershed Project Authority) (2014). Approximate Disposal

Cost for One Million Gallons of Brine Water- IEBrineline@sawpa.org

Http://offer.alibaba.com/product/premiumKeyword.vhtml?SearchText=evaporators,crystalizers,p ackaging units, pumps

Http://minerals.usgs.gov/minerals/pubs/commodity/lithium/mcs-2013-lithi.pdf

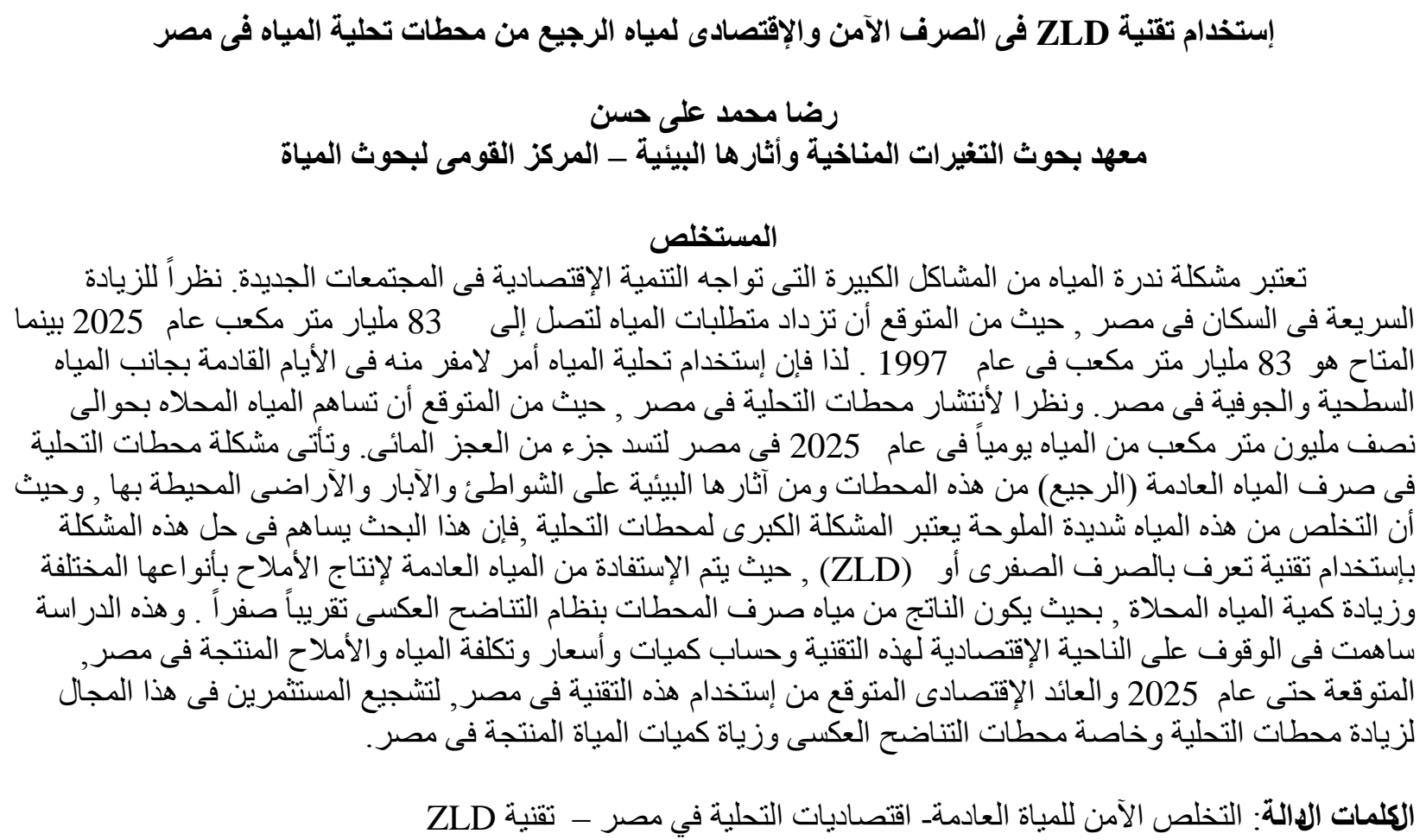

